\title{
Ground versus steam-rolled barley grain for lactating cows: A clarification into conventional beliefs
}

\author{
A. Soltani, ${ }^{*}$ G. R. Ghorbani, ${ }^{*}$ M. Alikhani, ${ }^{,}$A. Samie, ${ }^{*}$ and A. Nikkhah ${ }^{*}{ }^{1}$ \\ *Department of Animal Science, Isfahan University of Technology, Isfahan 84156, Iran \\ †Department of Animal Sciences, Zanjan University, Zanjan 313-45195, Iran
}

\begin{abstract}
Our objective was to compare the effects of grinding versus steam-rolling of barley grain at 30 or $35 \%$ of diet dry matter on feed intake, chewing behavior, rumen fermentation, and milk production in high-producing lactating cows. Eight multiparous Holstein cows (85 \pm $9 \mathrm{~d}$ in milk) were used in a replicated $4 \times 4$ Latin square design experiment with four 21-d periods. Each period included $14 \mathrm{~d}$ of adaptation and $7 \mathrm{~d}$ of sampling. Treatments included grinding (GB) or steam-rolling (SB) of barley grains at either 35 or $30 \%$ of dietary dry matter. Diets were prepared as a total mixed ration and delivered twice daily at 0730 and 1600 h. Neither processing method nor dietary barley grain inclusion rate affected dry matter intake, daily eating, ruminating and chewing times, rumen $\mathrm{pH}$ and major volatile fatty acid molar percentages, or milk percentages and yields of fat and protein. Energy-corrected milk yield increased for SB compared with GB at $35 \%$ but not at $30 \%$ barley grain. Feed efficiency was increased by SB, but was unaffected by dietary barley grain level. Results suggest that at $30 \%$ dietary barley grain, GB resulted in similar lactation performance as SB and that SB did not affect productivity when dietary barley grain increased from 30 to $35 \%$. Regardless of barley grain level, grinding effectively maintained dry matter intake and rumen $\mathrm{pH}$ at $4 \mathrm{~h}$ postfeeding, whereas steam-rolling increased feed efficiency. Increasing barley grain from 30 to $35 \%$ of diet dry matter did not improve feed intake and milk production.
\end{abstract}

Key words: barley grain, grinding, steam-rolling, lactating cow

\section{INTRODUCTION}

We have recently demonstrated that steam-rolling offers no digestive and productive advantages over

Received October 21, 2008.

Accepted February 24, 2009.

${ }^{1}$ Corresponding author: anikkha@yahoo.com or anikkhah@illinois. edu grinding at $26 \%$ dietary use of barley grain (Hordeum spp.; Sadri et al., 2007). Whole barley grain, rich in highly fermentable starch and protein (Ørskov, 1986; Herrera-Saldana et al., 1990), is not optimally digested by lactating cows (Valentine and Wickes, 1980). As a result, grinding and steam-rolling are commonly used to increase the availability of barley starch and protein to rumen microbes (Mathison, 1996; Yang et al., 2000). Unlike corn and sorghum, barley starch is not extensively integrated with slowly degradable protein matrices and it possesses greater effective DM degradability (e.g., 70 vs. 40\%; Herrera-Saldana et al., 1990; Nikkhah et al., 2004). Feeding processed barley grains at high dietary inclusion rates may increase the risk of subacute rumen acidosis (Owens et al., 1997) and asynchronize release of ATP and carbon skeleton and nitrogen compounds (Hall and Huntington, 2008). The elevated rumen VFA release caused by feeding a high amount of barley grain can increase blood insulin and depress milk yield (Ørskov, 1986). As conventionally believed, finely ground grains may depress feed intake by increasing ration dustiness and hastening the ruminal release of organic acids (Morrison, 1935; Mathison, 1996; Nikkhah and Ghorbani, 2003). Grinding, however, is an economical processing technique easily accessible to almost all dairy producers. We intuit that the dietary inclusion rate of barley grain is more critical than processing method for reducing the risk of subacute ruminal acidosis and attaining optimum immune function and economical milk production. Feeding diets with high barley starch and low effective $\mathrm{NDF}$ has lowered DMI and rumen $\mathrm{pH}$ and compromised immunity (Yang et al., 2000; Emmanuel et al., 2008). Based on rumen in situ studies, treating barley kernel with heat and moisture during the steam-rolling process may reinforce protein-starch and lipid-starch bonds and reduce the initial rumen degradation rate of barley endosperm (Arieli et al., 1995; Mathison, 1996; Ljøkjel et al., 2003a,b; Nikkhah and Ghorbani, 2003). Also, the coarser particles produced by steam-rolling may decrease the degradation rate of barley starch (Fiems et al., 1990; Nikkhah and Ghorbani, 2003; Tothi et al., 2003). However, these considerations have not been 
Table 1. Dry matter-based dietary ingredients at 35 and $30 \%$ barley grain

\begin{tabular}{lcc}
\hline & \multicolumn{2}{c}{ Dietary use of barley grain } \\
\cline { 2 - 3 } Ingredient & $35 \%$ & $30 \%$ \\
\hline Alfalfa hay & 15.4 & 15.4 \\
Corn silage & 23.0 & 23.0 \\
Barley grain (ground or steam-rolled) & 35.0 & 30.0 \\
Beet pulp & 4.5 & 9.4 \\
Soybean meal & 16.0 & 16.0 \\
Whole cottonseed & 3.9 & 4.0 \\
NaCl & 0.1 & 0.1 \\
Calcium carbonate & 0.2 & 0.2 \\
Sodium bicarbonate & 1.0 & 1.0 \\
Mineral and vitamin supplement ${ }^{1}$ & 0.9 & 0.9 \\
\hline
\end{tabular}

${ }^{1}$ Contained $250,000 \mathrm{IU} / \mathrm{kg}$ of vitamin A, 50,000 IU/kg of vitamin D, $1,500 \mathrm{IU} / \mathrm{kg}$ of vitamin E, $2.25 \mathrm{~g} / \mathrm{kg}$ of manganese, $120 \mathrm{~g} / \mathrm{kg}$ of calcium, $7.7 \mathrm{~g} / \mathrm{kg}$ of zinc, $20 \mathrm{~g} / \mathrm{kg}$ of phosphorus, $20.5 \mathrm{~g} / \mathrm{kg}$ of magnesium, $186 \mathrm{~g} / \mathrm{kg}$ of sodium, $1.25 \mathrm{~g} / \mathrm{kg}$ of iron, $3 \mathrm{~g} / \mathrm{kg}$ of sulfur, $1.25 \mathrm{~g} /$ $\mathrm{kg}$ of copper, $14 \mathrm{mg} / \mathrm{kg}$ of cobalt, $56 \mathrm{mg} / \mathrm{kg}$ of iodine, and $10 \mathrm{mg} / \mathrm{kg}$ of selenium.

conclusively tested by definitive in vivo comparisons of steam-rolling ( $\mathbf{S B}$ ) and grinding (GB) of barley grains for high-producing cows. Following our recent data and analogous cow performance on $\mathrm{GB}$ versus $\mathrm{SB}$ with a $26 \%$ dietary inclusion rate of barley grain (Sadri et al., 2007), our objectives were to compare the effects of grinding versus steam-rolling of barley grain at 30 or $35 \%$ of dietary DM on DMI; eating, ruminating, and chewing times; rumen fermentation at 4-h postfeeding; and lactation performance of high-producing cows.

\section{MATERIALS AND METHODS}

\section{Cows, Treatments, and Experimental Design}

Eight multiparous Holstein cows (85 \pm 9 DIM; $620 \mathrm{~kg}$ of BW; $43 \pm 2 \mathrm{~kg}$ of milk yield at the commencement of the study, mean $\pm \mathrm{SE}$ ) were used in a duplicated $4 \times 4$ Latin square design experiment with four 21-d periods. The Latin square was balanced for carry-over effects (Cochran and Cox, 1992). The cow parity was the square, with first- and second-lactation cows separated from older cows. Each period had $14 \mathrm{~d}$ of adaptation followed by $7 \mathrm{~d}$ of sampling and data collection. Cows were housed in individual free boxes $(4 \times 4 \mathrm{~m})$ and were allowed $1 \mathrm{~h}$ of daily exercise. Treatments were grinding (GB) or steam-rolling (SB) of barley grain at 30 or $35 \%$ of dietary DM (Table 1). In increasing the barley grain level from 30 to $35 \%$ of diet DM, barley grain replaced beet pulp. All diets were prepared as a TMR with $62 \%$ concentrate and $38 \%$ forage on a DM basis (Tables 2 and 3). Cows were offered the TMR twice daily at 0730 and $1600 \mathrm{~h}$, permitting 5 to $10 \%$ orts with unlimited access to fresh water and salty stones. Diets were formulated with the Cornell-Penn-Miner dairy program (CPM Dairy). The experiment was conducted during spring 2006 at the Dairy Facilities of the Lavark Research Station (Isfahan University of Technology, Iran) under the guidelines of the Iranian Council of Animal Care (1995).

\section{Sampling and Laboratory Analyses}

Feeds and Orts. The amount of TMR offered and orts were measured daily from d 15 to 20 of each period to calculate DMI for individual cows. Samples of TMR were taken daily for individual cows during the last $5 \mathrm{~d}$ of each period. Feed and ort samples were ovendried at $60^{\circ} \mathrm{C}$ for $48 \mathrm{~h}$, ground to pass through a $1-\mathrm{mm}$ screen using a Wiley mill (Arthur H. Thomas Co., Philadelphia, PA), and stored at $-20^{\circ} \mathrm{C}$ until analyzed for chemical composition. Feed samples were analyzed for CP (method 984.13; AOAC, 1990), NDF (Van Soest et al., 1991; using heat-stable $\alpha$-amylase and sodium sulfite), and ADF (method 973.18; AOAC, 1990). Organic matter was determined by ashing feed and fecal samples for $8 \mathrm{~h}$ at $550^{\circ} \mathrm{C}$.

Milking and Milk Sampling. Cows were milked 3 times daily at 0330,1300 , and $2130 \mathrm{~h}$. Milk production was recorded at each milking during the final $5 \mathrm{~d}$ of each period. The amount of milk produced for each cow at each milking was measured using standard graduated jars (Agri \& SD Co., Frankfort, Germany). Before each

Table 2. Chemical composition of forages and diets on a DM basis

\begin{tabular}{|c|c|c|c|c|}
\hline \multirow[b]{2}{*}{ Nutrient } & \multicolumn{2}{|c|}{ Forage } & \multicolumn{2}{|c|}{ Dietary barley grain ${ }^{1}$} \\
\hline & Alfalfa hay & Corn silage & $35 \%$ & $30 \%$ \\
\hline DM, \% & 95.2 & 24.1 & 60.0 & 61.0 \\
\hline CP, \% & 14.2 & 8.6 & 19.0 & 18.8 \\
\hline NDF, \% & 43.4 & 52.0 & 33.6 & 35.1 \\
\hline $\mathrm{ADF}, \%$ & 34.2 & 37.4 & 19.0 & 19.0 \\
\hline Starch, $\%$ & 2.8 & 26 & 28.0 & 25.6 \\
\hline $\mathrm{NE}_{\mathrm{L}},{ }^{2} \mathrm{Mcal} / \mathrm{kg}$ & 1.11 & 1.28 & 1.54 & 1.52 \\
\hline
\end{tabular}


Table 3. Chemical composition of concentrate ingredients (\% of DM)

\begin{tabular}{lccrrrr}
\hline Ingredient & DM & CP & NDF & ADF & Starch & Ether extract \\
\hline Barley grain & 91.0 & 11.0 & 20.8 & 7.2 & 59.0 & 2.3 \\
Beet pulp & 88.0 & 10.0 & 45.8 & 23.1 & 5.3 & 1.0 \\
Whole cottonseed & 91.0 & 23.2 & 50.3 & 40.1 & 3.4 & 18.5 \\
Soybean meal & 89.0 & 45.1 & 14.9 & 9.0 & - & 1.5 \\
\hline
\end{tabular}

milking cows were monitored for udder inflammation and presence of milk clots in the nipples to ensure that milk yield and composition were not affected by mastitis. No cases of mammary infections were observed during sampling weeks. Milk was sampled 3 times daily at each milking in prelabeled plastic vials, composited for individual cows, preserved with 2-bromo-2-nitropropan and potassium dichromate, and kept at $4^{\circ} \mathrm{C}$. Milk samples were analyzed for fat, protein, lactose, and total solids by MilkoScan (134 BN Foss Electric, Hillerød, Denmark).

Rumen Fluid and VFA Analyses. Using 4 cows, rumen fluid from the ventral sac was sampled by using a rumenocentesis technique (Nordlund and Garrett, 1994) $4 \mathrm{~h}$ after the morning feeding on the last day of each period. A $16-\mathrm{cm}^{2}$ area caudoventral to the costochondral junction of the last rib on a line parallel with the top of the patella was clipped and washed with alcohol. The shaved area was scrubbed with povidone-iodine and sovlorin cetrimide $\mathrm{C}(1.5 \% \mathrm{wt} / \mathrm{vol}$ chlorohexidine glucoronate and $15 \% \mathrm{wt} / \mathrm{vol}$ cetrimide; Damloron Co., Boroojerd, Iran), and was sedated by injecting $8 \mathrm{~mL}$ of $2 \%$ lidocaine-epinephrine solution to prevent bleeding. A stainless steel needle was inserted about $4 \mathrm{~cm}$ into the ventral sac of the rumen, and a 5 -mL syringe was used to aspirate rumen fluid. For $3 \mathrm{~d}$ after each sampling, cows were injected intramuscularly with penicillin-G-procaine to minimize any chance of infection. The $\mathrm{pH}$ of rumen fluid was measured immediately after sampling using a mobile $\mathrm{pH}$ meter (model 137243, Hanna, Lisbon, Portugal). To cease fermentation, $20 \mu \mathrm{L}$ of $50 \%$ sulfuric acid was added to rumen fluids, and samples were kept at $-20^{\circ} \mathrm{C}$ until analyzed for VFA using gas chromatography $(0.25 \times 0.32$, i.d. $0.3 \mu \mathrm{m}$, WCOT fused-silica capillary, Chrompack model CP-9002, Vulcanusweg, Delft, the Netherlands) as described by Bal et al. (2000).

Eating, Ruminating, and Chewing Activities. Eating and ruminating activities were monitored visually for a 24 -h phase on $\mathrm{d} 17$ of each period. The eating and ruminating activities were recorded once every 5 min under the assumption that each activity would persist for the entire $5 \mathrm{~min}$ (Yang et al., 2000). Total time spent chewing was calculated as the time spent eating plus the time spent ruminating. All activities were expressed per kilogram of DM, NDF, and ADF intake (Table 3).

\section{Barley Processing Techniques}

Barley grain (Hordeum spp.) was ground using a conventional hammer mill (model 5543 GEN, Isfahan Dasht, Isfahan, Iran) with a standard screen size of $1 \mathrm{~mm}$. Barley grains were screened during 2 separate steps and steamed for a minimum of 5 min at $102^{\circ} \mathrm{C}$ within a 4-m-high stainless steel chamber directly above the rollers (Nikkhah et al., 2004). Steamed grains had a moisture content of 18 to $20 \%$ as they were rolled between preheated corrugated rollers $(46 \times 90 \mathrm{~cm}$, Harris Co., Coalinga, CA). Rolled grains were passed through a channel under air pressure and were allowed to dry before storage and subsequent use in the diet. The steam-rolled barley had a processing index (PI) of $72 \%$. The PI was the ratio of density of rolled grains to density of whole grains $\times 100$ (Yang et al., 2000). For instance, if the density of whole and steam-rolled barley grains were on average 580 and $420 \mathrm{~g} / \mathrm{L}$, respectively, the PI for steam-rolled barley was $(420 / 580) \times 100$ or $72.4 \%$.

\section{Statistical Analysis}

Data were subjected to Proc Mixed (SAS Institute, 2003). The method of estimating least squares means was REML, and the method of calculating denominator degrees of freedom was Kenward-Roger (SAS Institute, 2003). The model included fixed effects of processing technique, barley grain inclusion rate, their interaction and square, plus random effects of period and cow within square. The model for rumen data included the fixed effects of processing method, barley grain percentage, and their interaction. Normality of distribution and homogeneity of residuals variance were tested using Proc Univariate (SAS Institute, 2003). When significant, the SAS option of PDIFF was used to separate the least squares means. The significant effects were declared at $P<0.05$ and trends were set at $P \leq 0.10$.

\section{RESULTS AND DISCUSSION}

\section{DM and Fiber Intakes}

Neither dietary level (35 vs. $30 \%, P=0.24$ ) nor processing method (ground vs. steam-rolled, $P=0.36$ ) of barley grain affected DMI (Table 3). Cows on GB 
and SB consumed 37.3 and 37.9 Mcal of $\mathrm{NE}_{\mathrm{L}}$ daily, respectively. Similar DMI data were consistent with our recent data (Sadri et al., 2007) using mid-lactation cows fed $26 \%$ ground, dry-rolled, or steam-rolled barley grain. Results suggest that even at high inclusion rates of barley grain, grinding maintains DMI compared with steam-rolling. The conventional belief that fine grinding produces dust, overly increases rumen fermentation rate, and depresses feed intake (Morrison, 1935; Mathison, 1996), has been based mainly on results from beef studies. Despite greater DMI of lactating cows compared with finishing beef cattle, dairy diets have much greater proportions of dry and ensiled roughages and lower percentages of concentrate. Such differences will alter the physical properties of the ration. Thus, extending the above notion to dairy diets and lactating cows requires caution and clarification. In the current study, barley grain increased in the diet at the expense of beet pulp, which is comparable to barley grain in CP content (10 vs. $11 \%$ ) and is rich in highly fermentable pectin and slowly degradable fiber (NRC, 2001; Table 3). The beet pulp replacement warrants consideration in interpreting DMI and productive response to dietary inclusion rate of barley grain (30 vs. 35\%). Recently, McGregor et al. (2007) reported no effects of feeding either finely $(\mathrm{PI}=69 \%)$ or coarsely $(\mathrm{PI}=83 \%)$ steam-rolled barley grain on DMI of mid and late lactation cows. In feedlot cattle, DMI was unaffected when dry-rolled, steam-rolled, or whole barley grains were fed (Owens et al., 1997). In another beef study (Zinn, 1993), coarse barley flakes did not affect DMI, whereas thin flakes tended to increase DMI. High-producing cows consume energy at much higher levels than do beef cattle; thus, comparing beef and dairy studies regarding treatment effects on DMI and rumen fermentation requires careful consideration of the differences in animal energetics. The DMI data alongside similar dietary $\mathrm{NE}_{\mathrm{L}}$ and $\mathrm{CP}$ concentrations for GB versus SB suggest that the potency of chemical constraints (e.g., rumen VFA; Allen, 2000) on short-term feed intake regulation were likely not different for GB compared with SB.

\section{Eating, Ruminating, and Chewing Times}

Eating time, whether daily ( 343.5 vs. $346.4 \mathrm{~min}$ ) or per kilogram of intake of DM (13.9 vs. $14.2 \mathrm{~min}$ ), NDF (34.9 vs. $35.5 \mathrm{~min}$ ), and $\mathrm{ADF}$ (62.5 vs. $64.9 \mathrm{~min}$ ), was not affected by grinding versus steam-rolling of barley grain $(P>0.10$, Table 4$)$, which agrees with comparable feed intake among treatments. Likewise, across barley grain inclusion rates, daily ruminating time (476.1 vs. $456.8 \mathrm{~min})$ and rumination per kilogram of intake of DM (19.3 vs. $18.7 \mathrm{~min})$, NDF (48.4 vs. $46.2 \mathrm{~min}$ ), and $\mathrm{ADF}$ (87.4 vs. $84.0 \mathrm{~min}$ ) were not influenced by GB versus SB $(P>0.10$, Table 4$)$. These similarities can be attributed to the comparable feed intake and daily ruminating time. The ruminating time (13 to $14 \mathrm{~min} /$ $\mathrm{kg}$ of DMI) agrees with other reports (Beauchemin et al., 2000; Maekawa et al., 2002). Considering the lower DMI in those studies compared with the present study (e.g., 17 to $21 \mathrm{~kg}$ vs. $24.8 \mathrm{~kg}$ ), we suggest that higher producing cows can consume more DM than lower producing cows mainly by spending more time eating, not necessarily by eating more quickly. Compared with an increased eating time, an increased eating rate is more likely to compromise rumen environment during larger meals, particularly shortly after feeding. Because of the unchanged eating and ruminating times, total chewing time daily and per kilogram of nutrient intake were unaffected by processing methods across the 2 barley inclusion rates. However, daily ruminating time was lower $(P=0.04)$ for SB at $30 \%$ of dietary DM than for GB at $30 \%$ of dietary DM (428.1 vs. $498.6 \mathrm{~min} / \mathrm{d}$ ). As a result, ruminating time per kilogram of DMI tended to be lower $(P=0.05)$ for SB at $30 \%$ than for GB at $30 \%$ $(17.5$ vs. $20.0 \mathrm{~min} / \mathrm{d})$. In view of the extensive fermentation of barley starch and protein (Herrera-Saldana et al., 1990), it is likely that barley grain particle size did not have a large effect on rumen mat properties. This view is in agreement with the comparable daily rumination time between SB and GB. A tendency $(P=$ $0.10)$ for greater rumination time per kilogram of ADF intake for GB at $30 \%$ of dietary DM $(91.8 \mathrm{~min} / \mathrm{d})$ than for SB at $30 \%(77.5 \mathrm{~kg} / \mathrm{d})$ might reflect prolonged fiber exposure to microbial enzymes for effective digestion. The consistent rumen fiber mat formation took place possibly earlier and was more efficient for SB at $30 \%$ than for GB at $30 \%$. The hypothetical reduction in rumen mat formation efficiency for GB at 30\% might be because of fine barley particles with high degradation and passage rates (Mertens, 1997).

\section{Rumen Fermentation}

Rumen $\mathrm{pH}$ and molar percentages of major VFA at 4-h after the morning feed delivery were unaffected by treatments (Table 5). Steam-rolling rather than grinding of barley grain increased $(P<0.01)$ isobutyrate and valerate concentrations, and tended to increase $(P$ $=0.06$ ) isovalerate concentration (Table 5). Branchedchain VFA (BCVFA) are products of AA metabolism in the rumen and play important roles in microbial energetics (Brockman, 2005). Because of the small contributions of BCVFA to milk production (Brockman, 2005), the effects of BCVFA on milk energy output are not as significant as the effects of major rumen VFA. Rumen data substantiate our previous findings in mid lactation cows at lower dietary inclusion rates of bar- 
Table 4. Treatment effects on nutrient intake and eating, ruminating, and chewing times

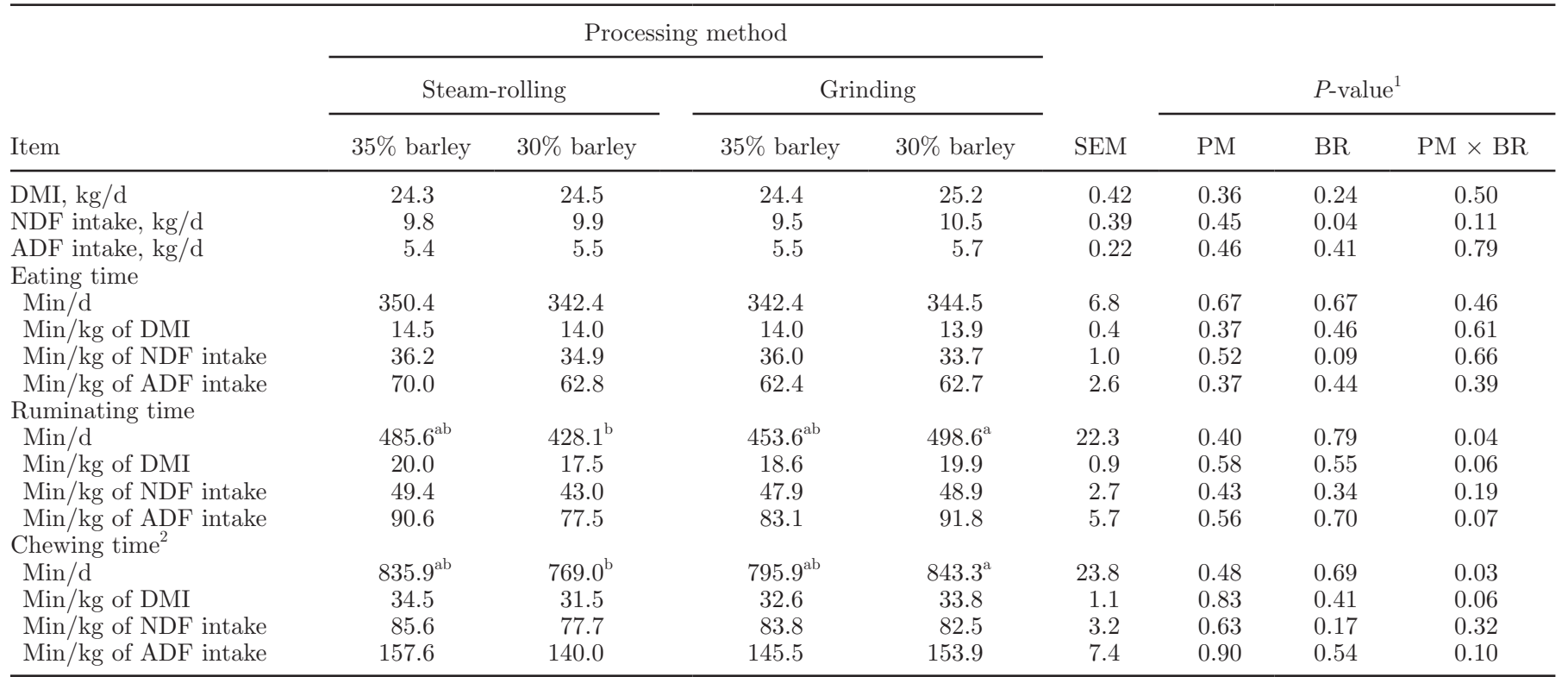

${ }^{\mathrm{a}, \mathrm{b}}$ Within each row, means with different superscripts differ at $P<0.05$.

${ }^{1} \mathrm{PM}=$ processing method; $\mathrm{BR}=$ barley grain use.

${ }^{2}$ Sum of eating and ruminating times.

ley grain (Sadri et al., 2007), providing evidence that grinding of barley grain at up to $35 \%$ of diet DM does not compromise rumen $\mathrm{pH}$ at $4 \mathrm{~h}$ after feeding. Rumen conditions were assessed using rumen fluid samples taken at $4 \mathrm{~h}$ after feeding when VFA concentrations were expected to be at peak (Stone, 2004). As such, the lack of a treatment difference in rumen $\mathrm{pH}$ when VFA molar percentages are at or near maximum fermentation suggests that grinding versus steam-rolling of barley grain at 35 or $30 \%$ of diet DM had little effect on rumen fermentation in cows with an average DMI of $24.8 \mathrm{~kg} / \mathrm{d}$. To determine longer term effects of barley grain inclusion rate on DMI, rumen acidity, and microbial shifts, larger and continuous herd studies through the entire early lactation are warranted.

\section{Milk Production}

Milk yield was not affected by processing method $(P=0.24)$ or dietary inclusion rate of barley grain $(P$ $=0.38$, Table 6 ). Milk fat, protein, SNF, and TS percentages and yields were also unaffected by treatments, supporting the results of Sadri et al. (2007). From a rumen health standpoint, these findings suggest that even in high-producing cows, increasing use of barley grain above certain limits (30\% in the current study) does not improve milk production. Feeding GB at $30 \%$ of diet DM $(37.3 \mathrm{~kg} / \mathrm{d})$ led to the same ECM as feeding SB at $30 \%(37.8 \mathrm{~kg} / \mathrm{d})$ and $\mathrm{SB}$ at $35 \%(37.5 \mathrm{~kg} / \mathrm{d})$, but GB at $35 \%(34.9 \mathrm{~kg} / \mathrm{d})$ decreased ECM compared with other treatments (Table 6). At both levels of barley

Table 5. Treatment effects on rumen fluid $\mathrm{pH}$ and VFA molar percentages at $4 \mathrm{~h}$ after the morning feed delivery (TMR was delivered twice daily at 0730 and $1600 \mathrm{~h}$ )

\begin{tabular}{|c|c|c|c|c|c|c|c|c|}
\hline \multirow[b]{2}{*}{ Item } & \multicolumn{2}{|c|}{ Processing method (PM) } & \multicolumn{2}{|c|}{ Barley use (BR) } & \multirow[b]{2}{*}{ SEM } & \multicolumn{3}{|c|}{$P$-value } \\
\hline & Steam-rolling & Grinding & $35 \%$ & $30 \%$ & & $\mathrm{PM}$ & $\mathrm{BR}$ & $\mathrm{PM} \times \mathrm{BR}$ \\
\hline Acetate & 68.3 & 68.0 & 67.6 & 68.6 & 1.0 & 0.87 & 0.44 & 0.42 \\
\hline Propionate & 17.3 & 19.5 & 18.9 & 17.8 & 0.9 & 0.13 & 0.43 & 0.40 \\
\hline Butyrate & 8.8 & 9.6 & 9.1 & 9.3 & 0.5 & 0.34 & 0.86 & 0.41 \\
\hline Isovalerate & 1.4 & 0.8 & 1.1 & 1.0 & 0.3 & 0.06 & 0.69 & 0.29 \\
\hline Acetate:propionate & 4.0 & 3.6 & 3.7 & 3.9 & 0.2 & 0.22 & 0.45 & 0.21 \\
\hline
\end{tabular}


Table 6. Treatment effects on milk production and feed efficiency

\begin{tabular}{|c|c|c|c|c|c|c|c|c|}
\hline \multirow[b]{2}{*}{ Item } & \multicolumn{4}{|c|}{ Processing method (PM) } & \multirow[b]{2}{*}{ SEM } & \multicolumn{3}{|c|}{$P$-value } \\
\hline & $35 \%$ barley & $30 \%$ barley & $35 \%$ barley & $30 \%$ barley & & $\mathrm{PM}$ & $\mathrm{BR}^{1}$ & $\mathrm{PM} \times \mathrm{BR}$ \\
\hline Milk yield, $\mathrm{kg} / \mathrm{d}$ & 38.3 & 38.8 & 36.9 & 38.0 & 0.8 & 0.24 & 0.38 & 0.72 \\
\hline $4 \%$ FCM, $\mathrm{kg} / \mathrm{d}$ & 35.4 & 35.7 & 33.4 & 35.3 & 0.8 & 0.17 & 0.19 & 0.32 \\
\hline $\mathrm{ECM}, \mathrm{kg} / \mathrm{d}^{2}$ & $37.5^{\mathrm{a}}$ & $37.8^{\mathrm{a}}$ & $34.9^{\mathrm{b}}$ & $37.3^{\mathrm{a}}$ & 0.9 & 0.09 & 0.12 & 0.23 \\
\hline Milk fat, $\%$ & 3.36 & 3.47 & 3.38 & 3.6 & 0.14 & 0.89 & 0.42 & 0.46 \\
\hline Fat yield, $\mathrm{kg} / \mathrm{d}$ & 1.39 & 1.35 & 1.24 & 1.34 & 0.04 & 0.25 & 0.26 & 0.33 \\
\hline Milk protein, \% & 2.87 & 2.86 & 2.85 & 2.87 & 0.02 & 0.88 & 0.97 & 0.58 \\
\hline Protein yield, kg/d & 1.09 & 1.11 & 1.04 & 1.09 & 0.03 & 0.16 & 0.26 & 0.53 \\
\hline Milk lactose, $\%$ & $5.47^{\mathrm{a}}$ & $5.42^{\mathrm{ab}}$ & $5.45^{\mathrm{ab}}$ & $5.37^{\mathrm{b}}$ & 0.03 & 0.30 & 0.05 & 0.78 \\
\hline Lactose yield, $\mathrm{kg} / \mathrm{d}$ & 2.10 & 2.11 & 2.02 & 2.05 & 0.05 & 0.21 & 0.70 & 0.46 \\
\hline Milk SNF, $\%$ & 8.54 & 8.47 & 8.56 & 8.45 & 0.07 & 0.95 & 0.20 & 0.75 \\
\hline
\end{tabular}

${ }^{\mathrm{a}, \mathrm{b}}$ Within each row, values with different superscripts differ at $P \leq 0.05$.

${ }^{1} \mathrm{BR}=$ barley grain use.

${ }^{2}$ Energy-corrected milk calculated as $(\mathrm{kg}$ of milk $\times 0.3246)+(\mathrm{kg}$ of milk fat $\times 12.96)+(\mathrm{kg}$ of milk protein $\times 7.04) ;$ Jenkins et al. $(1998)$.

grain, SB consistently increased feed efficiency compared with GB $(P<0.01)$, which was a cumulative effect of the numerical increase and decrease in milk yield and DMI, respectively (Table 6). Overall, therefore, treatments had smaller effects on productivity with a more pronounced effect on feed efficiency. The increased feed efficiency by steam-rolling was about $4.7 \%$. Because the average dietary barley grain use was $32.5 \%$ on a DM basis, the barley-related improvement in efficiency was about $15 \%$. This means that based on the results of the current study, steam-rolling of barley could be affordable if steam-rolling costs no more than $15 \%$ of the cost of grinding. In addition, the greater the difference between milk price and feed cost, the greater the economic magnitude of improved feed efficiency by steam-rolling.

Milk protein percentage $(P=0.88)$ and yield $(P=$ $0.16)$ were not affected by processing techniques. In addition, increasing barley grain use from 30 to $35 \%$ of dietary DM did not affect milk protein percentage $(P$ $=0.97)$ or protein yield $(P=0.26)$. We suggest that differently processed barley grains at both the 30 and $35 \%$ dietary inclusion rates did not influence microbial protein synthesis, intestinal AA delivery, or mammary AA supply. These data are in accordance with the comparable DMI and rumen VFA data. Feeding barley grain at $35 \%$ instead of $30 \%$ of the diet DM tended to increase milk lactose percentage $(P=0.05)$. Given the precise statistical analysis and the low standard error, biological interpretation of the 0.04- to 0.05-percentageunit increase in milk lactose percentage requires caution. Because of the similar milk SNF percentage and yield,
TS percentage and yield was similar among treatments. Milk production data provided no basis for the primacy of steam-rolling over grinding at $30 \%$ barley grain in the diet, whereas steam-rolling positively affected milk energy output at $35 \%$ dietary barley grain.

\section{CONCLUSIONS}

Grinding has conventionally been considered a risk to DMI and rumen function, although it is an accessible technique to process barley grain. Steam-rolling is believed to reduce such risks but is more expensive than grinding. When the DM of TMR contained $30 \%$ barley grain, grinding resulted in similar feed intake, rumen fermentation at $4 \mathrm{~h}$ postfeeding, and milk production compared with steam-rolling. Grinding increased daily ruminating and chewing times at $30 \%$ barley grain in the diet. Compared with grinding, steam-rolling of barley increased feed efficiency at both barley inclusion rates and positively affected milk energy output only at the $35 \%$ inclusion rate. Increasing barley grain use from 30 to $35 \%$ in the diet of high-producing cows did not improve cow performance.

\section{ACKNOWLEDGMENTS}

The authors acknowledge Isfahan University of Technology (Isfahan, Iran) for financial support and teaching facilities and acknowledge the employees of the Lavark Research Station (Isfahan University of Technology, Iran) for cow care. 


\section{REFERENCES}

Allen, M. S. 2000. Effects of diet on short-term regulation of feed intake by lactating dairy cattle. J. Dairy Sci. 83:1598-1624.

AOAC. 1990. Official Methods of Analysis. 15th ed. Assoc. Off. Anal. Chem., Arlington, VA.

Arieli, A., I. Bruckental, O. Kedar, and D. Sklan. 1995. In sacco disappearance of starch nitrogen and fat in processed grains. Anim. Feed Sci. Technol. 51:287-295.

Bal, M. A., R. D. Shaver, A. G. Jirovec, K. J. Shinners, and J. G. Coors. 2000. Crop processing and chop length of corn silage: Effects on intake, digestion, and milk production by dairy cows. J. Dairy Sci. 83:1264-1273.

Beauchemin, K. A., L. M. Rode, M. Maekawa, D. P. Morgavi, and R. Kampen. 2000. Evaluation of a nonstarch polysaccharidase feed enzyme in dairy cow diets. J. Dairy Sci. 83:543-553.

Brockman, R. P. 2005. Glucose and short chain fatty acid metabolism. Pages 157-176 in Quantitative Aspects of Ruminant Digestion and Metabolism. 2nd ed. J. Dijkstra, J. M. Forbes, and J. France, ed. CABI Publishing, Wallingford, UK.

Cochran, W. G., and G. M. Cox. 1992. Experimental Designs. 2nd ed. Wiley-Interscience Publications, New York, NY.

Emmanuel, D. G., S. M. Dunn, and B. N. Ametaj. 2008. Feeding high proportions of barley grain stimulates an inflammatory response in dairy cows. J. Dairy Sci. 91:606-614.

Fiems, L. O., B. G. Cottyn, Ch. V. Boucque, J. M. Vanacker, and F. X. Buysse. 1990. Effect of grain processing on in sacco digestibility and degradability in the rumen. Arch. Anim. Nutr. 40:713-721.

Hall, M. B., and G. B. Huntington. 2008. Nutrient synchrony: Sound in theory, elusive in practice. J. Anim. Sci. 86(E Suppl.):E287E292.

Herrera-Saldana, R. E., J. T. Huber, and M. H. Poore. 1990. Dry matter, crude protein, and starch degradability of five cereal grains. J. Dairy Sci. 73:2386-2393.

Iranian Council of Animal Care. 1995. Guide to the Care and Use of Experimental Animals. Vol. 1. Isfahan University of Technology, Isfahan, Iran.

Jenkins, T. C., J. A. Bertrand, and W. C. Bridges Jr. 1998. Interactions of tallow and hay particle size on yield and composition of milk from lactating Holstein cows. J. Dairy Sci. 81:1396-1402.

Ljøkjel, K., O. M. Harstad, E. Prestløkken, and A. Skrede. 2003a. In situ digestibility of protein in barley grain (Hordeum vulgare) and peas (Pisum sativum L.) in dairy cows: Influence of heat treatment and glucose addition. Anim. Feed Sci. Technol. 107:87-104.

Ljøkjel, K., O. M. Harstad, E. Prestløkken, and A. Skrede. 2003b. In situ digestibility of starch in barley grain (Hordeum vulgare) and peas (Pisum sativum L.) in dairy cows: Influence of heat treatment and glucose addition. Anim. Feed Sci. Technol. 107:105-116.

Maekawa, M., K. A. Beauchemin, and D. A. Christensen. 2002. Effect of concentrate level and feeding management on chewing activities, saliva production, and ruminal $\mathrm{pH}$ of lactating dairy cows. J. Dairy Sci. 85:1165-1175

Mathison, G. W. 1996. Effects of processing on the utilization of grain by cattle. Anim. Feed Sci. Technol. 58:113-125.
McGregor, G., M. Oba, M. Dehghan-Banadaky, and R. Corbett. 2007. Extent of processing of barley grain did not affect productivity of lactating dairy cows. Anim. Feed Sci. Technol. 138:272-284.

Mertens, D. R. 1997. Creating a system for meeting the fiber requirements of dairy cows. J. Dairy Sci. 80:1463-1481.

Morrison, F. B. 1935. Chapter 4: Factors affecting the value of feeds. Pages 59-71 in Feeds and Feeding. The Morrison Publishing Co. Ithaca, NY.

National Research Council. 2001. Nutrient Requirements of Dairy Cattle. 7th rev. ed. National Academy Press, Washington, DC

Nikkhah, A., M. Alikhani, and H. Amanlou. 2004. Effects of feeding ground or steam-flaked broom sorghum and ground barley on performance of dairy cows in midlactation. J. Dairy Sci. 87:122130

Nikkhah, A., and G. R. Ghorbani. 2003. Effects of dry and steam processing on in situ ruminal digestion kinetics of barley grain. J. Anim. Sci. 81(Suppl. 1):338. (Abstr.)

Nordlund, K. V., and E. F. Garrett. 1994. Rumenocentesis: A technique for collecting rumen fluid for the diagnosis of subacute rumen acidosis in dairy herds. Bovine Pract. 28:109-112.

Ørskov, E. R. 1986. Starch digestion and utilization in ruminants. J. Anim. Sci. 63:1624-1633.

Owens, F. N., D. S. Secrist, W. J. Hill, and D. R. Gill. 1997. The effect of grain source and grain processing on performance of feedlot cattle: A review. J. Anim. Sci. 75:868-879.

Sadri, H., G. R. Ghorbani, M. Alikhani, M. Babaei, and A. Nikkhah. 2007. Ground, dry-rolled, and steam-rolled barley grain for midlactation Holstein cows. Anim. Feed Sci. Technol. 138:195204

SAS Institute. 2003. SAS User's Guide. Version 9.1 ed. SAS Institute Inc., Cary, NC.

Stone, W. C. 2004. Nutritional approaches to minimize subacute ruminal acidosis and laminitis in dairy cattle. J. Dairy Sci. 87(E Suppl.):E13-E26.

Tothi, R., P. Lund, M. R. Weisbjerg, and T. Hvelplund. 2003. Effect of expander processing on fractional rate of maize and barley starch degradation in the rumen of dairy cows estimated using rumen evacuation and in situ techniques. Anim. Feed Sci. Technol. 104:71-94.

Valentine, S. C., and R. B. Wickes. 1980. The production and composition of milk from dairy cows fed hay supplemented with whole, rolled or alkali treated barley grain. Proc. Aust. Soc. Anim. Prod. 13:397-400.

Van Soest, P. J., J. B. Robertson, and B. A. Lewis. 1991. Methods for dietary fiber, neutral detergent fiber, and nonstarch polysaccharides in relation to animal nutrition. J. Dairy Sci. 74:3583-3597.

Yang, W. Z., K. A. Beauchemin, and L. M. Rode. 2000. Effects of barley grain processing on extent of digestion and milk production of lactating cows. J. Dairy Sci. 83:554-568.

Zinn, R. A. 1993. Influence of processing on the comparative feeding value of barley for feedlot cattle. J. Anim. Sci. 71:3-10. 